\title{
KEPEMIMPINAN INFORMAL BERBASIS PARTISIPASI MASYARAKAT DALAM MENJAGA KETAHANAN PANGAN LOKAL
}

\section{INFORMAL LEADERSHIP BASED ON COMMUNITY PARTICIPATION IN MAINTAINING LOCAL FOOD SECURITY}

\author{
G Pratidina1a, N S Zenju1, Sukarelawati1, B Sastrawan'1 \\ ${ }^{1}$ Program Studi Administrasi Publik, Fakultas Ilmu Sosial Dan Ilmu Politik, Universitas Djuanda ${ }^{\text {Il }}$ Tol \\ Ciawi No 01, Kotak Pos 35 Ciawi Bogor 16720. \\ a Korespondensi:Ginung Pratidina, E-mail: ginung.pratidina@unida.ac.id \\ (Diterima: 20-02-2020; Ditelaah: 22-02-2020; Disetujui: 26-03-2020)
}

\begin{abstract}
Leadership is the most important factor in the management of groups and organizations, so that appropriate leadership is needed in achieving organizational goals. The Sundanese Indigenous People (Kasepuhan) are unique communities to be investigated inasmuch as the indigenous leaders in their leadership have success in managing their local food so they rarely experience food shortages. One contributing factor is informal leadership based on community participation carried out by indigenous leaders. Therefore, this study aims to analyze the informal leadership of indigenous leaders based on community participation in maintaining local food security using descriptive analysis methods. Data were collected using literature study and observation techniques by distributing questionnaires and in-depth interviews, then the data were analyzed using analysis techniques Weight Mean Score (WMS). The results showed that the informal leadership of indigenous leaders based on community participation had a value of 3.22 on a scale of 4 . this value is interpreted well. Based on observations and interviews with indigenous Kasepuhan Sinar Resmi Chiefs, two-way communication in conducting deliberations on each issue, because these indigenous communities focus on the culture of planting Sawah and Huma only once a year and starting from planting to harvest are carried out simultaneously, so that what is unique's the indigenous head as the authority in making decisions when to plant to harvest, its members have high obedience, members Kasepuhan do not dare to plant first if the indigenous head has not started planting. This strength participation of indigenous people can maintain local food security in the region until now.
\end{abstract}

Keywords: Indigenous People; Local Institutions; Leadership. 


\begin{abstract}
ABSTRAK
Kepemimpinan merupakan faktor terpenting dalam pengelolaan kelompok maupun organisasi, sehingga dibutuhkan kepemimpinan yang tepat dalam mencapai tujuan organisasi. Masyarakat Adat Sunda (Kasepuhan) merupakan masyarakat yang unik untuk diteliti karena kepala adat dalam kepemimpinannya memiliki keberhasilan dalam mengelola pangan lokal mereka sehingga hampir tidak pernah mengalami kekurangan pangan. Salah satu faktor penyebabnya adalah kepemimpinan informal berbasis partisipasi masyarakat yang dilakukan oleh kepala adat. Tujuan dari penelitian ini adalah untuk menganalisis kepemimpinan informal kepala adat berbasis partisipasi masyarakat dalam menjaga ketahanan pangan lokal dengan menggunakan metode deskriptif analisis. Data diambil menggunakan teknik studi literatur dan Observasi dengan penyebaran kuesioner dan wawancara mendalam, kemudian data tersebut dianalisis dengan teknik analisis Weight Mean Score (WMS). Hasil penelitian menunjukkan bahwa kepemimpinan informal Kepala Adat berbasis partisipasi masyarakat memiliki nilai 3,22 dari skala 4 dengan penafsiran baik. Berdasarkan hasil observasi dan wawancara kepala adat Kasepuhan Sinar Resmi melakukan komunikasi dua arah dalam melakukan musyawarah setiap permasalahan, karena masyarakat adat ini fokus pada budaya menanam padi sawah dan huma hanya setahun sekali dan mulai dari menanam hingga panen dilakukan secara serentak, sehingga yang menjadi keunikan adalah kepada adat sebagai otoritas dalam mengambil keputusan kapan menanam hingga memanen, anggotanya memiliki ketaatan yang tinggi, anggota Kasepuhan tidak berani menanam lebih dahulu kalau kepala adatnya belum memulai menanam. Partisipasi inilah yang menjadi kekuatan masyarakat adat sehingga bisa menjaga ketahanan pangan lokal di daerahnya hingga sekarang.

Kata Kunci: Kelembagaan Lokal, Kepemimpinan, Masyarakat Adat

Pratidina, G., Zenju, N. S,. \& Sastrawan, B. (2020). Kepemimpinan Informal Berbasis Partisipasi Masyarakat dalam Menjaga Ketahanan Pangan Lokal. Jurnal Sosial Humaniora, 11(1), 98-104.
\end{abstract}

\section{PENDAHULUAN}

Indonesia merupakan negara yang memiliki kekayaan budaya dan kearifan lokal yang luarbiasa data dari Kemdikbud pada tahun 2019 Indonesia memiliki Cagar Budaya yang tercatat resmi sebanyak 2319. (PDSPK Kemdikbud, 2019). Selain itu, Indonesia juga merupakan negara agraris dimana sektor pertanian merupakan sektor yang penting untuk dibangun dan diperhatikan karena merupakan kebutuhan primer manusia yaitu pangan. Apalagi di Desa mayoritas memiliki profesi sebagai petani. Maka dari itu, masyarakat Indonesia tidak lepas dari kebudayaan dalam bercocok tanam salah satunya pangan yang banyak ditanami adalah sawah yang menghasilkan beras yang sampai kepada kita saat ini. Perpaduan adat istiadat dengan pertanian ini sejak dahulu sudah mendarah daging oleh masyarakat desa dahulu. Salah satunya adalah masyarakat adat yang masih teguh dalam memegang, menjaga, memelihara dan menerapkan tradisi leluhur dalam bercocok tanam tradisional yang masih organik tanpa pupuk kimia dan terbukti memiliki ketahanan pangan lokalnya yaitu Masyarakat Adat Sunda (Kasepuhan) Sinar Resmi yang berada di wilayah administrasi Desa Sirnaresmi Kecamatan Cisolok Kabupaten Sukabumi Jawa Barat.

Ketahanan pangan yang dilakukan di Desa tersebut salah satunya adalah Kepemimpinan Informal yang dilakukan oleh Kepala Adat yang biasa disebut dengan Abah. Sehingga menarik untuk dilakukan penelitian bagaimana sinergitas antara pemimpin formal yaitu pemerintah Desa, Kecamatan, Kabupaten dan Pusat dengan pemerintahan informal yaitu kelembagaan dan kepemimpinan adat. Kelembagaan adat selama puluhan tahun telah berhasil melakukan ketahanan 
pangan lokalnya yaitu padi dengan cara tradisional dan organik. Salah satu faktor keberhasilan yang menjadi asumsi peneliti adalah partisipasi dari masyarakat adat dan kepala adat yang menjadi contoh adalah salah satu faktor yang mempengaruhi dalam mempertahankan ketahanan pangan lokal di Desa tersebut yang akan dibuktikan dalam pembahasan.

\section{MATERI DAN METODE}

Penelitian mengenai kepemimpinan sudah banyak dilakukan oleh peneliti-peneliti dimanapun. Maka dari itu, mayoritas hasil penelitian membuktikan bahwa Kepemimpinan merupakan salah satu faktor kunci dalam menjalankan organisasi dan menjadi pengaruh kepada hal-hal lainnya. Salah satu penelitian mengenai kepemimpinan adalah dari Jurnal Sosial Humaniora Universitas Djuanda dengan Judul Pengaruh Stres Kerja dan Kepemimpinan terhadap Kinerja Karyawan, hasil penelitiannya tentang kepemimpinan menunjukkan bahwa variabel kepemimpinan berpengaruh positif dan nyata kepada kinerja karyawannya. (Septiana, Harini, \& Sudarijati, 2018)

Sedangkan penelitian tentang partisipasi masyarakat juga sudah banyak dilakukan oleh peneliti-peneliti sebelumnya. Salah satunya penelitian dengan judul Partisipasi Masyarakat dalam Perencanaan Pembangunan di Kecamatan Cibadak Kabupaten Sukabumi, hasil penelitiannya menunjukkan bahwa Partisipasi masyarakat dalam perencanaan pembangunan di Kecamatan Cibadak Kabupaten Sukabumi masih rendah, hal ini dapat dilihat dari: Pertama, fokus perencanaan belum berdasarkan pada masalah dan kebutuhan masyarakat, belum memperhatikan aspirasi masyarakat yang memenuhi sikap saling percaya dan terbuka; kedua, masyarakat secara keseluruhan belum memperoleh peluang yang sama dalam menyumbangkan pemikiran dan masih terkendala waktu dan tempat, masyarakat belum dilibatkan dalam memutuskan kegiatan yang akan dijadikan prioritas untuk diusulkan ke jenjang yang lebih tinggi; ketiga, unsur sinergitas sudah berjalan dengan baik; Keempat, unsur legalitas perencanaan belum dilaksanakan dengan baik, dimana perencanaan pembangunan yang dilaksanakan di Kecamatan Cibadak kabupaten Sukabumi belum mengacu pada peraturan yang berlaku. (Purnamasari, 2011)

Hasil Penelitian yang sudah ada mengenai Ketahanan Pangan Lokal di Sinar Resmi adalah Tesis dari Universitas Brawijawa yang menunjukkan bahwa bentuk-bentuk kearifan lokal dalam menjaga ketahanan pangan di Kasepuhan Sinar Resmi yaitu dengan cara tetap menjalankan aturan yang telah ditetapkan secara turun-temurun diantaranya: konsep Ngaji Diri merupakan falsafah atau pandangan hidup warga Kasepuhan yang diturunkan oleh leluhur yang dijalankan dalam kehidupan sehari-hari. Budaya Pamali (aturan), contohnya aturan dalam pengelolaan pertanian, bahan pangan (padi), penggunaan bahan bangunan, larangan untuk menjual beras dan padi. Selanjutnya budaya gotong-royong dalam melakukan proses pertanian yang dilakukan secara bersama-sama seperti penanaman padi serempak, pengurusan irigasi secara bersama-sama dan panen padi bersamaan. Salah satu strategi ketahanan pangan masyarakat Kasepuhan Sinar Resmi tetap melestarikan Leuit. Kehadiran Leuit ikut mengatur ketersediaan pangan di desa yang jauh dari perkotaan. Cara melestarikan benih lokal di Kasepuhan Sinar Resmi dengan cara setiap warga wajib menanam padi lokal sebanyak tiga atau lima jenis padi lokal. Tradisi masyarakat Kasepuhan tidak dapat lepas dari peranan Ketua Adat yang menjadi sumber utama informasi. Sikap patuh di masyarakat yang mempengaruhi adalah kuatnya budaya paternalistik yang berkembang di Kasepuhan. (Pratiwi, 2017) 
Gaya partisipasi yaitu pemimpin dengan gaya partisipasi menekankan pada banyak memberikan dukungan dan sedikit dalam pengarahan. Pemimpin menyusun keputusan bersama-sama dengan para bawahan saling tukar-menukar ide/gagasan dan mendukung usaha-usaha mereka dalam menyelesaikan tugas. Posisi kontrol atas pemecahan masalah dan pembuatan keputusan dipegang secara bergantian. Komunikasi dua arah ditingkatkan dan peranan pemimpin secara aktif mendengarkan. Hal ini wajar karena bawahan/pengikut telah memiliki kemampuan untuk melaksanakan tugas. (Hersey \& H. Blancard, 2012)

Penelitian ini menggunakan metode deskriptif analisis dengan teknik pengambilan data menggunakan studi literatur dan Observasi melalui pengamatan langsung di lapangan, penyebaran kuesioner/angket dan wawancara mendalam. Kemudian setelah data dikumpulkan dipilih data yang relevan, ditabulasi dan dianalisis dengan menggunakan teknik analisis Weight Mean Score (WMS).

\section{HASIL DAN PEMBAHASAN}

Kepemimpinan Kepala adat dalam memecahkan permasalahan didominasi oleh gaya partisipasi dengan nilai sebesar 3,22 dari skala 4, dimana kepala adat ketika ada masalah di masyarakat terkadang ke kepala adat yang menyelesaikan jika itu berkaitan dengan adat, namun apabila tidak maka diselesaikan oleh mereka sendiri dan melalui kepemimpinan formal seperti RT dan RW. Berdasarkan hasil Observasi di lapangan, apabila ada permasalahan berkaitan dengan adat contoh dalam pertanian sawah, pasti masyarakat mendatangkan kepala adat untuk menyelesaikan permasalahan, namun apabila permasalahan tidak berkaitan dengan kelembagaan adat seperti ada program pemerintah desa, maka biasanya diselesaikan oleh Kepala Desa atau RT/RW.

Dalam kelembagaan adat sunda terdapat konsep Sara, Nagara dan Mokaha, Sara merupakan Urusan Agama, Nagara adalah urusan kenegaraan, kerjasama antar lembaga non-adat dan urusan luar negeri dan Mokaha adalah urusan adat istiadat, kesejahteraan dan pertanian. Ketiga urusan ini saling bekerjasama dalam menyelesaikan urusannya, memiliki tugasnya masing-masing, Sara dipimpin oleh tokoh agama yaitu ustadz yang dalam acara adat selalu memimpin doa, dan urusan keagamaan masyarakat, urusan Nagara dipimpin oleh orang yang ahli dalam diplomasi menyelesaikan permasalahan antara kelembagaan seperti contoh dalam permasalahan antara TNGHS dengan kelembagaan adat (Kasepuhan) dan Mokaha adalah urusan adat istiadat, pertanian, kesejahteraan, tapal batas wilayah yang dipimpin langsung oleh kepala adat yang disebut Abah. Ketiga kepemimpinan ini konsep unik dalam aturannya tidak bertentangan satu sama lain, dalam konsep ini juga tidak ada yang paling tinggi dan tidak ada yang paling rendah ketiga konsep ini sejajar, karena tiga konsep ini masyarakat adat sering menganalogikan Sara adalah Ruhnya, Nagara adalah Fisiknya dan Mokaha adalah pakaiannya. Maka ketika kelembagaan adat mengabaikan Sara, maka sama dengan manusia yang mati yang hanya ada fisik dan pakaiannya, apabila mengabaikan Nagara maka sama dengan hantu karena tidak memiliki fisik, dan apabila mengabaikan mokaha maka seperti orang gila dan tidak beradab/hewan yaitu tidak berpakaian. Secara bergantian masalah agama, urusan kenegaraan, dan adat ketiga ini saling bergantian menyelesaikan masalah, contoh ketika masalah kenegaraan adat, terkadang diselesaikan oleh bagian kenegaraan adat terkadang oleh kepala adat tergantung kondisi dan situasinya, jika situasinya tidak terlalu penting dan mendesak maka langsung diambil inisiatif 
namun jika itu membutuhkan keputusan kepala adat, penting dan mendesak maka secara bersama-sama dan berkoordinasi diselesaikan oleh kepala adat secara langsung. Disini komunikasi dan koordinasi penting dalam memecahkan sebuah permasalahan. Pada Gambar 1 terdapat Struktur Kelembagaan Adat Sinar Resmi.

\section{Gambar 1. Struktur Kelembagaan} Kasepuhan Sinar Resmi

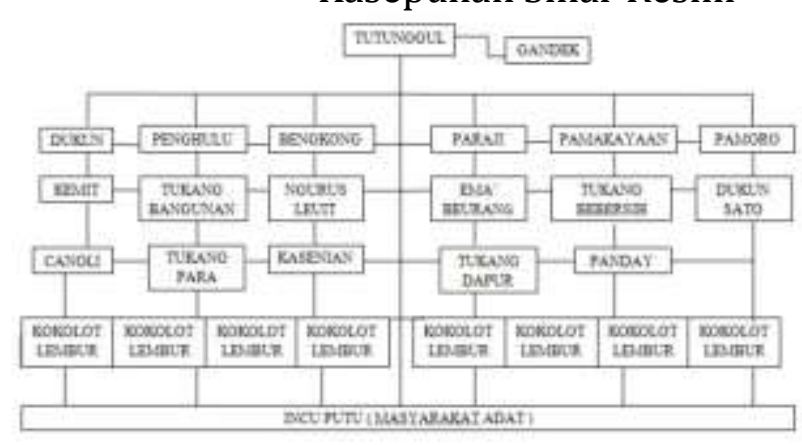

Sumber : (Rahmawati, Pratidina, Salbiah, \& Sastrawan, 2017)

Sedangkan dalam menjaga ketahanan pangan lokal (padi) pada masyarakat adat Sinar Resmi yang menjadi kunci adalah yang pertama adanya pelarangan yang kuat dan ditaati bagi semua anggota masyarakat adat untuk menjual padi, beras ataupun nasi. Namun apabila saling meminjam dan memberi tidaklah dilarang. Masyarakat mempercayai bahwa jika menjual beras atau padi akan mendatangkan sial, penyakit atau karma kepada penjual beras tersebut. Namun apabila diteliti secara rasionalitas dan pengamatan. Masyarakat adat Sinar Resmi memiliki nilai keprofesian sebagai petani, bahwa setiap anggota adat pada dasarnya adalah petani, menurut mereka petani bukan hanya sekedar profesi saja, namun petani adalah cara dan nilai hidup mereka. Maka dari itu, setiap orang memiliki tanah untuk ditanami padi. Sehingga ketika mereka tidak memiliki apa-apa, paling tidak mereka masih memiliki beras untuk dimakan sehari-hari. Kunci selanjutnya adalah mereka memiliki bangunan penyimpanan beras yaitu lumbung padi yang disebut dengan Leuit. Dimana penyimpanan ini menjaga suhu padi supaya tetap stabil, terhindar dari hama bahkan berdasarkan dari wawancara masih ada padi yang sudah disimpan puluhan tahun masih tersimpan ada. Strategi ketiga yang menjadi kunci adalah kepemimpinan informal berbasis partisipasi masyarakat adat dalam pengelolaan pertanian sawah dan huma, dimana dalam pengelolaan pertanian sawah menganut sistem serempak dalam penanaman padinya, mulai dari pembenihan, bercocok tanam bahkan sampai panen serempak dimana dalam penentuan mulai menanam sampai panen dalam penanggalannya ditentukan oleh Kepala Adat berdasarkan penglihatan kepala adat dengan melihat bintang dan hitungan di kalender seperti halnya ilmu astronomi, ilmu ini didapatkan dari turun temurun melalui lisan ke lisan, yang menjadi keunikan tersendiri adalah kebudayaan dan kearifan lokal serta ketaatan dari masyarakat kepada kepala adat yang begitu dalam, sebagai contoh tidak ada satupun yang berani dari anggota adat yang berani menanam lebih dahulu ataupun panen terlebih dahulu apabila kepala adat belum memerintahkan dan melaksanakan terlebih dahulu oleh kepala adat. Ini bermakna bahwa kepala adat adalah sebagai contoh dan teladan bagi masyarakat adat. Selain itu setiap tahapan dalam pertanian sawah mulai dari pertama menanam sampai dengan panen selalu ada acara Syukuran atau Selametan yaitu memohon kepada Tuhan supaya diberi kelancaran dan keberkahan. Apabila diteliti lebih dalam secara rasional dengan adanya penanaman serempak ini membuat hama padi menjadi terbagi kebanyak lahan, sebaliknya apabila tidak serempak, hama padi setiap waktu akan berpindah ke tempat lainnya yang berdekatan terus menerus. Kemudian selain itu, hikmah dibalik penanaman serempak adalah adanya saling gotong royong sesama masyarakat yaitu dengan sistem utang piutang tenaga, dimana setiap orang 
membantu membajak lahan orang lain apabila diminta membantu, kemudian ketika selesai membantu sebaliknya yang dipinjam tenaga untuk membajak lahan, selanjutnya membayar utang tenaga yang sebelumnya. Sehingga pekerjaan membajak sawah yang memang diwajibkan tradisional menjadi ringan karena dibantu banyak orang dan dicicil sedikit demi sedikit. Maka dari itu keunikan dari pengelolaan pertanian sawah pada masyarakat adat Sinar Resmi adalah sawah organik sehingga berasnya memiliki kesehatan yang tinggi. dari segi sirkulasi tanah, masyarakat adat hanya menanam padi setahun sekali dengan cara tradisional, bahkan dalam membajak sawah tidak boleh memakai memakai mesin dalam menggiling padi menjadi beras tidak boleh memakai mesin harus ditumbuk secara tradisional sehingga beras menjadi sedikit halus sehingga ketika dimasak dan dimakan mudah untuk dicerna. Bahkan sampai memasak berasnya pun tidak boleh menggunakan kompor gas atau minyak apalagi rice cooker listrik. Semua aturan tersebut tidak bisa dilaksanakan tanpa kepemimpinan yang kuat yang dilakukan oleh Kepala Adat dalam menjaga tradisi dan ketahanan pangan.

Selain faktor kepemimpinan kepala adat, ada faktor lainnya yaitu partisipasi masyarakat yang diperlihatkan dari tingkat kematangan anggota kasepuhan yang bekerja sesuai dengan tugasnya, tugas atau amanah tersebut didapatkan berdasarkan turun temurun. Sehingga Kepala Adat bisa memastikan bahwa anggota masyarakat adat yang disebut Incuputu melakukan tugasnya yang diamanahkan oleh orangtua sebelumnya, melaksanakan tugasnya tanpa menunggu instruksi dari Abah, karena tugas mereka adalah rutinitas tahunan dan profesi dalam kepengurusan adat didapat berdasarkan keturunan dari orang tuanya, hanya saja masyarakat adat menunggu waktu yang telah diputuskan oleh kepala adat kapan dilaksanakan kegiatan tersebut yang tentu ditentukan sebelumnya berdasarkan perhitungan dari bintang atau bulan. Maka dari itu sesuai hasil penelitian dominasi dari tingkat kematangan bawahan pada masyarakat adat adalah Sedang ke Tinggi. Tabel 1 menunjukkan perangkatperangkat yang ada di kelembagaan Kasepuhan.

Tabel 1. Perangkat-perangkat Kasepuhan Berdasarkan Fungsinya

\begin{tabular}{|c|c|}
\hline Jabatan & Fungsi \\
\hline $\begin{array}{l}\text { Kanagaraan } \\
\text { (Kepala } \\
\text { urusan luar } \\
\text { kampung) }\end{array}$ & $\begin{array}{l}\text { Membantu Abah dalam } \\
\text { semua permasalahan } \\
\text { yang terkait dengan } \\
\text { pemerintah. Sebagai } \\
\text { penasihat Abah ketika } \\
\text { ada isu-isu yang terjadi di } \\
\text { komunitas. }\end{array}$ \\
\hline $\begin{array}{l}\text { Syara' } \\
\text { (Kepala } \\
\text { urusan } \\
\text { agama) }\end{array}$ & $\begin{array}{lr}\text { Membantu Abah dalam } \\
\text { permasalahan } & \text { yang } \\
\text { terkait dengan hukum } \\
\text { adat dan agama. }\end{array}$ \\
\hline $\begin{array}{l}\text { Panghulu } \\
\text { (Kepala } \\
\text { urusan adat) }\end{array}$ & $\begin{array}{l}\text { Sebagai pemimpin doa } \\
\text { dalam ritual-ritual adat. } \\
\text { Menyiapkan segala } \\
\text { keperluan } \\
\text { pemakaman, untuk } \\
\text { menentukan biaya untuk } \\
\text { pemakaman. }\end{array}$ \\
\hline $\begin{array}{l}\text { Tatanen } \\
\text { (Pengatur air) }\end{array}$ & $\begin{array}{l}\text { Mengkoordinasi } \\
\text { manajemen sawah dan } \\
\text { sistem irigasi. } \\
\text { Menghukum orang-orang } \\
\text { yang ikut campur dalam } \\
\text { mensuplai air. }\end{array}$ \\
\hline $\begin{array}{l}\text { Dukun } \\
\text { Manusia } \\
\text { (Penyembuh } \\
\text { orang) }\end{array}$ & $\begin{array}{l}\text { Memimpin ritual-ritual } \\
\text { untuk mencegah dan } \\
\text { mengobati penyakit. } \\
\text { Memberikan obat-obatan } \\
\text { dan menentukan biaya } \\
\text { untuk pengobatan. }\end{array}$ \\
\hline $\begin{array}{l}\text { Dukun Hewan } \\
\text { (Penyembuh } \\
\text { hewan) }\end{array}$ & $\begin{array}{l}\text { Mengobati hewan yang } \\
\text { sakit. }\end{array}$ \\
\hline
\end{tabular}




\begin{tabular}{|c|c|}
\hline Jabatan & Fungsi \\
\hline $\begin{array}{l}\text { Panyawah } \\
\text { (Pengatur } \\
\text { urusan } \\
\text { sawah) }\end{array}$ & $\begin{array}{l}\text { Mengawasi } \\
\text { mengurus } \\
\text { komunal }\end{array}$ \\
\hline $\begin{array}{l}\text { Paraji } \\
\text { (Bidan) }\end{array}$ & $\begin{array}{l}\text { Membantu } \\
\text { melahirkan }\end{array}$ \\
\hline $\begin{array}{l}\text { Moro } \\
\text { (Pemburu) }\end{array}$ & $\begin{array}{l}\text { Memburu hewan untuk } \\
\text { ritual adat mengusir } \\
\text { hama yang mengganggu }\end{array}$ \\
\hline $\begin{array}{l}\text { Kemit } \\
\text { (Penjaga) }\end{array}$ & $\begin{array}{l}\text { orang yang bertugas } \\
\text { menjaga keamanan } \\
\text { wilayah tempat tinggal }\end{array}$ \\
\hline $\begin{array}{l}\text { Ganek/Koja } \\
\text { (Asisten } \\
\text { abah) }\end{array}$ & $\begin{array}{lrr}\text { Mendampingi } & \text { abah } \\
\text { ketika } & \text { melakukan } \\
\text { perjalanan } & \text { ke luar } \\
\text { kampung } & & \end{array}$ \\
\hline
\end{tabular}

Sumber: (Marina, 2011).

\section{KESIMPULAN}

Kepemimpinan informal Kepala Adat berbasis partisipasi masyarakat memiliki nilai 3,22 dari skala 4 dengan penafsiran baik. Berdasarkan hasil observasi dan wawancara kepala adat Kasepuhan Sinar Resmi melakukan komunikasi dua arah dalam melakukan musyawarah setiap permasalahan, karena masyarakat adat ini fokus pada budaya menanam padi sawah dan huma hanya setahun sekali dan mulai dari menanam hingga panen dilakukan secara serentak, sehingga yang menjadi keunikan adalah kepada adat sebagai otoritas dalam mengambil keputusan kapan menanam hingga memanen, anggotanya memiliki ketaatan yang tinggi, anggota Kasepuhan tidak berani menanam lebih dahulu kalau kepala adatnya belum memulai menanam. Partisipasi inilah yang menjadi kekuatan masyarakat adat sehingga bisa menjaga ketahanan pangan lokal di daerahnya hingga sekarang.

\section{DAFTAR PUSTAKA}

Hersey, P., \& H. Blancard, K. (2012). Kepemimpinan Birokrasi (Terjemahan Harbani Pasolong, Ed.). Bandung: Alfabeta.

Marina, I. (2011). Analisis Konflik Sumberdaya Hutan di Kawasan Konservasi. https://doi.org/https://doi.org/10.2 2500/sodality.v5i1.5830

PDSPK Kemdikbud. (2019). Statistik Kebudayaan 2019. Diambil dari http://publikasi.data.kemdikbud.go.i d/uploadDir/isi_B8CE5CF3-4C7640D6-9E7D-79FB8B708096_.pdf

Pratiwi, R. E. (2017). Strategi Komunikasi Berbasis Kearifan Lokal Dalam Upaya Penguatan Lumbung Pangan (LEUIT) Untuk Menunjang Ketahanan Pangan (Studi Kasus Kampung Adat Kasepuhan Sinar Resmi, Desa Sirna Resmi, Kecamatan Cisolok, Kabupaten Sukabumi, Provinsi Jawa Barat) (Universitas Brawijaya). Diambil dari http://repository.ub.ac.id/4822/

Purnamasari, I. (2011). Partisipasi Masyarakat dalam Perencanaan Pembangunan di Kecamatan Cibadak Kabupaten Sukabumi. Sosial Humaniora, 2(1), 89-101. https://doi.org/http://dx.doi.org/10. 30997/jsh.v2i1.88

Rahmawati, R., Pratidina, G., Salbiah, E., \& Sastrawan, B. (2017). Buku Pedoman Pariwisata Budaya: Mengenal Masyarakat Kasepuhan Sinar ResmiTaman Nasional Gunung Halimun Salak. Bogor: Unida Press.

Septiana, A., Harini, S., \& Sudarijati. (2018). Pengaruh Stres Kerja dan Kepemimpinan terhadap Kinerja Karyawan. Sosial Humaniora, 9(1), 34-47. https://doi.org/http://dx.doi.org/10. 30997/jsh.v9i1.1377 